QUADERNS DE FILOSOFIA VOL. VI NÚM. 2 (20I9): 43-6I

eISSN: 234I-3042 DOI: I0.7203/QFIA. 6.2.I6054

JULIA JAKOBI ${ }^{1}$

Universität Hamburg

\title{
The Egalitarian Quality of Lottocracy
}

Received: 15/7/19. Accepted: 16/9/19

\begin{abstract}
Recently, political models which employ lottery-selection instead of ballot voting have been proposed. Proponents argue that such lottocratic models can improve the representation of the population and reduce undemocratic influences. In this paper, I argue that these proposals also satisfy the egalitarian requirement of democracy. I claim that having an equal chance to be selected by lot is equally egalitarian as having an equally weighed vote for two reasons: first, having a chance to be selected by lot satisfies the requirement for political justice better than electoral democracy and second, it provides citizens with an equal chance on political influence and not merely equal impact.
\end{abstract}

Keywords: lottocracy, procedural democracy, political equality, political fairness, egalitarian democracy.

\section{INTRODUCTION}

T $\mathrm{T}$ IS WIDELY HELD THAT DEMOCRACY is the most desirable political system, 1 at least amongst those currently at choice. Nevertheless, it has always been questioned and debated whether or not there are political systems that could be preferred, and if so, why. For instance, several authors have doubted that democratic systems can claim any authority towards their citizens at all (cf. i.a. EstLund 2008; Huemer 20 I3). And although it is broadly defended that political systems should be democratic in order to be legitimate, democracy is, however, a very vague concept that allows for a high range of different pro-

${ }^{1}$ Mail to: julia.jakobi@uni-hamburg.de. 
cesses and organizational characteristics. Originally, the term "democracy" derives from the ancient Greek words "demos", the people, and "kratos", strength (cf. ROBERTSON 2004, 136). Thus, literally speaking, any form of government might be considered democratic as long as the political power is ultimately in the hand of the totality of the (adult) citizens and no smaller group has the power to rule. One famous definition of democracy describes it as "government of the people, by the people, for the people" (LinCOLN I 863).

It is often assumed that a government by the people requires a general and equal right to vote for all citizens. But historically speaking, elections have not always been an element of democracy. In ancient Greece, for example, political offices were distributed via lot amongst all citizens ${ }^{2}$ (cf. FucHs 2009, 39f). Discussions and deliberation on political decisions were held in public during which every citizen was allowed to express his opinion on a topic. The randomly selected citizens were then in charge to enact the politics decided upon. Officials were replaced every year so that almost every citizen held a political office at least once in a lifetime (Ibid., 40). As a result of an increasing population such inclusive democracies were replaced by representative democracies: market-place discussions were transferred into parliament and lottery selection was replaced by elections as an element of participation and inclusion of the general public (Ibid., 41). Nowadays, only states which hold elections are considered democratic, but, from a historical point of view, elections have not always been taken as a necessary element of democracy.

Recently, political theorists have proposed different lottocratic models which reintroduce the use of lotteries as an element of political systems (cf. i.a. Fishkin, 2009, 2018; Guerrero, 20I4; López-Guerra, 201 i ; SaunDeRS, 20io; VAN ReYBroucK, 20 i 8). They argue that through lottery-selection the participation of the general public could be enhanced, the impact of lobbyists and economic interests reduced, the demographic representation of the population enlarged and the acceptance of controversial political decisions improved. Experiments with randomly selected citizen assemblies have generated positive results both in terms of the quality of the decisions and of the perception of the decision-process (cf. i.a. BERBNer et al. 20I7; FISHKIN 20I8; Van Reybrouck 20I6).

When it comes to justifying democracy as the desirable political system, mainly two lines of argumentation are employed: democracy is stressed to be valuable for either instrumental or egalitarian reasons. Instrumental accounts of democracy argue that, compared to other decision-methods, democratic decision-making generally leads to good and epistemically valu-

\footnotetext{
${ }^{2}$ Only men of a certain class were considered decent citizens; women, slaves and other people from lower and working classes were not included in the selection of politicians.
} 
able results (cf. i.a. ARNeSON 2009; EstLund 1997). Egalitarian arguments of democracy, by contrast, refer to the intrinsic value of equality which is inherent to the method and independent from the consequences of the decision. Such intrinsic arguments stress the importance of procedural fairness and the general virtue of the equality of all citizens (cf. i.a. Christiano I996A; 2018).

If one generally accepts that democratic systems are justified, then, in order to legitimate the aforementioned lottocratic proposals, it has to be justified that such systems would satisfy the instrumental and the egalitarian value of democracy or it has to be shown that only one of these dimensions is relevant in order for something to be a legitimate and desirable political system. Generally, I follow the first of these approaches and assume that a political system should satisfy the instrumental and egalitarian requirements. In this paper, however, I focus merely on the egalitarian value of lottocracy. The aim of this paper is to show that lottocratic systems satisfy the intrinsic and procedural value of democracy in a relevant way despite depriving people of their general right to vote, a right which is typically considered the characteristic of equal participation in political decision-making. I will not address the epistemic quality of the proposed lottocratic model. I consider the quality of the decisions taken a necessary criterion for legitimating a political system, but I have to leave the evaluation of this quality for another discussion.

The criticism raised against electoral democratic systems is to a certain degree unfair: whenever it comes to evaluating lottocratic proposals one can only discuss ideal, potential designs of them, while the criticism brought forward against electoral systems is based on non-ideal, actual realizations. In what follows, I do not intend to argue that the lottocratic proposal is the only system which could mitigate the problems of current electoral democracies, nor that electoral systems could not be improved in a way to avoid some of the criticism. Instead, I want to evaluate the democratic potential of such lottocratic models in terms of political equality.

I will begin by giving a brief introduction to how a particular lottocratic system is supposed to work (Section 2). I will then outline why political equality is generally considered a necessary element of a desirable political system (Section 3). Next, I will discuss two possible understandings of political equality and question to what extent the lottocratic model could satisfy them: first, political equality as political justice (Section 4) and second, political equality as vertical equality of influence (Section 5). Finally, I will summarize my arguments in order to evaluate the democratic potential of lottocracy (Section 6). 


\section{LOTTOCRACY}

In this paper, I will focus on one extreme proposal for lottery-selection within political systems put forward by Alexander Guerrero (2014). He proposes a model which he calls Lottocracy and in which politicians would no longer be elected but be randomly selected out of the totality of all citizens currently entitled to vote. Other proposals in a similar vein discuss lotteryselected assemblies with advisory functions (FISHKIN 2009; 2018), distributing the right to vote by lottery (López-Guerra 20II) or randomly selecting one final decision out of all votes casted (SAUNDERS 20IO). I will focus on Guerrero's proposal for two reasons: I consider it most comprehensive and promising in order to address the criticism put forward against electoral democracies and it builds on positive empirical findings made in so called citizen assemblies and mini-publics (cf. i.a. FisHKin 2009).

The basic idea of a lottocracy is that politics are no longer made by an elected parliament but by members of the society, which are randomly drawn by lot from the totality of all citizens currently entitled to vote 3 . In order to get a better grasp of the idea of lottocracy I will briefly outline some of the main points of Guerrero's proposals. Nevertheless, my arguments do not hinge on the specific set-up of the system but basically on the fact of replacing a right to vote by a chance to be selected.

Guerrero is very detailed in explaining some of the aspects of the system but completely leaves aside others. He only focuses on the composition and operation of the legislative branch, the parliament, but does, for example, not address the selection of the executive branch, the government. In Guerrero's proposal, the randomly selected people would become full-time, paid politicians for three years. They would get relevant expert-input on political topics, participate in deliberations and become empowered and qualified to take informed decisions on topics relevant to the society. Every year one third of the selected people would be replaced by a new lottery in order to ensure a constant workflow while at the same time rotating the group of politically active people and frequently integrating new and unbiased perspectives. People would not be obliged to serve once they are drawn, but the financial incentives would be considerable and the civic culture should be developed in a way that serving as a politician is "one of the most significant civic duties and honors" (GUerRERO, 20I 4: 156). Guerrero points out that, considering the current costs of the

\footnotetext{
${ }^{3}$ Whether there should be restrictions such as a maximum age, health conditions or a criminal history to exclude people from the possibility of being selected is one of the practical issues that this paper does not focus on, as well as the question whether people could be obliged to take over a political office.
} 
political system in the United States, each selected member of the legislature might be paid something between US $\$ 500,000$ and US $\$ 1,000,000$ per year. Already smaller amounts than these should make it highly attractive for the larger part of the population to assume a political job for three years especially since efforts would be made to accommodate family and work schedules, provide relocation expenses and to guarantee the return into former jobs $s^{4}$. There should be some mechanisms to exclude people who frequently do not show up, who show up intoxicated or who are disrespectful or offensive, but these mechanisms would have to be set in a way that they "protect those who simply are unlikable or who have divergent views" (Ibid., 156).

An intensive deliberation phase, consisting both of expert-input and extensive discussions with other members or the legislature, who might have very different attitudes or social background, is one of the core elements of the lottocratic system 5 . In addition to the internal deliberation, Guerrero proposes that the selected politicians should also interact with the general public somehow, for example through virtual discussion platforms or, better, by going back into their home regions and holding something like town-hall meetings or panel discussions. Thereby, they could both inform nonmembers about the issues and proposals under discussion and gather information of the public's opinions and concerns (Ibid., 162).

This paper will not question the practical setup of the system nor the quality of its decisions. Questions that would have to be answered are how the experts should be selected, whether people can be forced to become politicians, whether there should be a combination of elections and lotteries, who would take on representative functions and the like. I will skip all such considerations and, given the positive results of different experiments with randomly selected citizen-assemblies, assume that integrating the general public into the political

${ }^{4}$ For reasons of individual freedom and autonomy it seems highly disputable whether one could force someone to spend three years of her life in a job that he or she has not chosen voluntarily, to serve the society in a way that most other citizens never do and to interrupt whatever other occupation he or she is currently following. Such an obligation would require a substantial justification that will not be further pursued or debated in this paper. It would have to be discussed elsewhere to what extent the quality of the system might be questioned if participation is voluntary.

5 The selection of these experts is one crucial point in Guerrero's proposal to ensure the quality of the decisions and the absence of manipulation and unfair influences. It requires a "qualification assessment process" to determine if a person counts as an expert and an "expert selection process" to decide which qualified experts are given the opportunity to speak. I will not further discuss a feasible mechanism of expert selection here. For the course of this paper it shall suffice to assume that some good and fair way of integrating experts into the process could be established. Moreover, when it comes to criticizing the influence of experts, it should be kept in mind that all currently practiced political systems do in some way build on advisory services, which are oftentimes not strictly regulated or democratically legitimated. 
system by lottery selection instead of by ballot voting is somehow promising. In the following, I will focus on the question whether such a system could claim to fulfill the egalitarian virtues of democracy.

\section{The Value of Equality}

Before entering into the analysis of different possible interpretations of political equality I will briefly mention some general assumptions on why it is considered valuable at all. There are two lines of arguing for equality as the relevant criterion and justification of democracy: One that stresses the intrinsic value of equality and one that values the procedural advantages of equal consideration given the epistemic limits of knowledge and agreement. The value of equality of all human beings is widely accepted and, inter alia, stipulated in the first article of The Universal Declaration of Human Rights:

All human beings are born free and equal in dignity and rights. They are endowed with reason and conscience and should act towards one another in a spirit of brotherhood.

Although many philosophers have tried to argumentatively prove the desirability of equality, it is often accepted to have an intrinsic value that needs no formal proof (cf. i.a. RaWLS I97I) ${ }^{6}$. As Thomas Christiano puts it

It is an elementary requirement of justice that individuals ought to be treated equally if they are equal in the relevant ways and may be treated unequally if they are unequal in a relevant way. Each person has an equally important life to live, so there is a strong presumption in favor of his or her interests being given equal consideration (CHristiano i996B, 33).

A second line of argument that justifies democracy due to its egalitarian value stresses the procedural fairness of democratic systems. Proceduralist justifications of democracy favor fair procedures as the relevant criterion for justifying democracy. They argue that it is sometimes difficult to identify the epistemic quality of political decisions and that due to the existing pluralism of values and the lack of shared convictions on morality, religion, the best economic system and the like, it is often difficult to reach an agreement about controversial decisions which may not have only one, correct result (cf. CoHEN I996, 18). Proceduralists therefore stress the procedural value of democracy,

\footnotetext{
${ }^{6}$ For interesting counter positions to this assumption see i.a. Frankfurt (1987; 2000).
} 
arguing that the fact of being a fair and egalitarian procedure gives people reasons to accept decisions which might not be clearly judgeable on epistemic grounds (cf. EstLund I997, 174f).

Given the difficulty of reaching content-based agreement, proceduralists argue that it is more important to focus on decision procedures that can be accepted by everyone affected. They claim that the virtue of being an "intrinsically fair political procedure [...] can outweigh some shortfall in production of good consequences" (ARNESON 2009, 200) and that electoral democracy ${ }^{7}$ delivers fair results because it takes into account the opinion of every citizen equally. Thus, democracy leads to a solution that appropriately considers the different opinions present in a society. Procedural arguments build on the intrinsic value of equality and rate it higher than the ideal, but according to them unrealizable, aim of epistemically best decisions.

Of course, merely procedural justifications of democracy are frequently criticized. It is often argued that majority rule can lead to unfair, undesirable and content-wise inferior results. Moreover, critics claim that a merely procedural approach to political decisions is problematic since it is self-defeating: if disagreement on matters of principle are to be solved by fair procedures, how ought one decide which procedure is fair, given the disagreement on principles? (cf. CHRIsTIANO I996B, 35). On the other hand, proponents of proceduralism stress the intrinsic value of treating people equally and consider democratic majority rule an intuitively desirable system. In this paper, I am not concerned with solving the disagreement between proceduralists and instrumentalists and will not further discuss criticism against both positions here. Given the amount of convincing arguments for egalitarian positions, I will assume that a desirable political system has to somehow accommodate the value of equality. As Charles Beitz states it, "no theory of democracy that failed to give the egalitarian idea a central place could possibly yield a faithful representation of the extraordinary grip of democracy on the modern political imagination" (I989, xi). The proposed lottocratic model would deprive people of one important form of equal participation: it would replace their equal vote by only an equal chance on becoming selected as a politician. Several interpretations of political equality exist and I will show how lottocratic models satisfy some relevant interpretations of political equality and why they do so even better than current electoral democratic systems. In what follows, I will elaborate on two interpretations of political equality and the respective egalitarian potential of a lottery-based political system.

${ }^{7}$ Throughout this paper, I will often refer to what is commonly considered a democracy - to electoral, representative democracy - when I speak of "democracy" although I want to challenge whether not a system with universal lottery selection of politicians instead of elections could be called democratic as well. 


\section{Political Equality as Political Fairness}

I will first consider a procedural interpretation of political equality and suggest that political equality ought to be understood as political fairness. When it comes to claiming political equality necessary for something to be a desirable political system, it has to be defined how political equality should be interpreted. The claim for political equality demands to establish fair terms of participation which treat all citizens as equal and in a fair manner. Formulations such as "providing everyone with an equal say in politics" or "providing everyone with an equal opportunity to influence politics" are often used synonymously, but I want to put forward that egalitarian requirements towards a political system can be satisfied by an equal but relevant opportunity on significant influence, even without providing everyone with an equal say. Lottocratic systems would deprive people of an equal say in politics but provide them with an equal chance on relevant influence.

Political equality is often said to imply that the power to take political decisions is equally in the hand of all people. The adequate decision procedure to enact popular sovereignty is often assumed to be one which provides every citizen with an equal say in political decisions. According to most egalitarian democrats, "political equality implies that each and every citizen ought to have a say" (Christiano I996B, 45) in political decisions. I want to argue that providing people with an equal say is one interpretation of political equality but not the unique or best one. To say that the people are sovereign and govern themselves does not necessarily mean that everyone has to have an equal say. In electoral democracies, all citizens have an equal vote but every vote has a very small actual influence. An equal vote seems to rather a symbolic than consequentialist value. But what I take to be, what I take to be the more relevant interpretation of political equality is to have an equal opportunity on meaningful political participation.

Let me support this claim with some numbers ${ }^{8}$. In Germany, in the last elections 61.5 million people were entitled to vote. They elected 709 Members of Parliament. If everyone had participated in the elections, the voice of every voter would have had an impact of $0.0012 \%$ on the election

${ }^{8}$ In the following, I will build my argumentation on numbers and ratios from Germany. It might make a slight difference if the number of people living in a jurisdiction is significantly smaller, but I assume that mathematics of large numbers would lead to similar results in most democratic states. The figures are only approximate and simplified calculations. I will not further discuss the German electoral system with its particularities of a so-called mixed-member proportional representation or the like. I only provide these numbers in order to catch a glimpse of the dimensions under discussion here. 
of one member of the parliament. In other words: every Member of Parliament is elected by 86,700 people; every vote influences the composition of the parliament by $0.0000017 \%$.

How relevant is the voice one has in politics if every four years one can influence the election of one of about seven hundred Members of Parliament by a share of $0.0012 \%$ ? Given these numbers, I question if the claim for political equality, expressed by an equal say, should be interpreted to be a consequential claim. Instead, I consider it to be a rather symbolic claim. I grant that political equality should be understood as equalizing the public status of democratic citizens (cf. BEITZ I989, 16f), but I do not think that this is best done by providing everyone with an equal vote. I do not question that providing people with equal votes is a possibility of realizing a certain kind of political equality, but I question if it is the best we can do in order to achieve meaningful political equality. Instead, I suggest that political equality should be understood as providing citizens with equal procedural opportunities to influence political decisions. Charles Beitz equals the opportunity to influence political decisions with having equal power over outcomes (cf. I989, $4 \mathrm{f})$, but I doubt that these two interpretations of equality do indeed imply the same. As I have pointed out above, it is questionable whether practically all citizens can be provided with a relevant power over political outcomes at all. I do not question the claim for procedural fairness, but I suggest that political equality can also be realized by an equal distribution of access to relevant political influence. Although the lottocratic proposal does not provide everyone with power over political outcomes, it does provide an equal opportunity on influence.

Ronald Dworkin argues that the aim of any political process should be to improve equality of political power (cf. DwORKIN 1987, 117f). He interprets political equality not necessarily as an equal say in politics but as an ideal striving for an equal distribution of political power. Elections are only one means to provide people with political power, but a very un-influential one. As I have pointed out, actual numbers suggest that providing people with one vote every four years does not provide every single one of them with significant power at all.

When the opportunity of gaining political power is evaluated, not only the active right to vote but especially the passive right to become elected should be considered. Although, legally speaking, in most electoral democracies every adult has both an active and a passive voting right, it is questionable to what extent the passive right to vote is indeed realized. The necessity of a significant financial wealth for becoming a politician in the US is frequently discussed, but also in Germany systemic hurdles prevent 
people from becoming politicians with actual, significant influence9 . Political offices are mainly accessible to people with a solid financial background and a relatively high educational level. Research suggests that the passive voting right, the right to become an eligible candidate, is in many societies effectively not realized ${ }^{10}$ (cf. i.a. GUerrero 20 I 4; Helm 20 I7). In Germany, beside of the elected members of the parliament, between 1000 and 4000 people can be considered to constitute a powerful, political influential but not democratically legitimated elite, as sociologists specialized in researching social elites state (cf. i.a. Cwiertnia 20i 8; Hartmann 20i8).

When it comes to equalizing access to real political power, providing people with an actually equal chance of becoming a politician seems to be more promising than to provide people merely with a right to vote. To equalize the distribution of political power, systemic hurdles have to be reduced and the access to political offices has to be improved. Regarding such an equal distribution of political power, a lottocratic system would provide people with an actual chance on political power. In most electoral democracies, all people are provided with an equal vote but effectively only few are provided with a possibility to become politically influential. I do not suggest that lottocracy is the only way to improve the access to political offices or that electoral democracies could not be improved with regard to a more effective realization of a passive voting right. What I want to point out here is that the lottocratic proposal does realize a relevant claim for political equality and does so better than electoral democracies currently do maybe even better than they can do in an ideal realization, given that elections always require some kind of pre-selection of eligible candidates.

So far, I have suggested that political fairness is a sufficient realization of the requirement of political equality. I have argued that political equality has a rather symbolic than a consequentialist value if it is provided by giving

\footnotetext{
${ }^{9}$ The political scientist Marion Reiser found that candidates in the parliamentary elections have to finance large parts of their election campaigns privately. The political scientist Bernhard Weßels states that the direct candidates of the largest two parties paid in average between $10,500 €$ and $6,600 €$ of their private money for their campaigns which were financed to only $13-50 \%$ by their parties (cf. HeLm 20I7). In the US, campaign financing is even way more expensive (cf. GUERRERO 2OI4).

${ }^{10}$ The accessibility of political offices can be doubted, given that the composition of the parliament is not at all representative for the composition of the society. The last German parliament consisted of academics by $91 \%$ while the society as a whole consists of less than $15 \%$ academics (cf. Schmidt-Mattern 20is; Statistisches Bundesamt 20I7). Migratory backgrounds and age structures are equally underrepresented in the parliament. Legally it is provided, but effectively it is questionable if young, female migrants really have the same passive voting right a fifty-year-old German men.
} 
people one vote in elections. The political power one has by having one vote is so small that a system that provides the citizens with actual influence in a fair way might be more promising. What is important to realize political fairness is that people are treated as equals and have equal access to political offices, but this does not necessarily imply that all political rights have to be distributed equally amongst all. The requirement of political fairness can be sufficiently satisfied as long as the terms of participation are such that no citizen has sufficient reasons to deny them, given the general desire to come to an agreement on some mechanism of participation. A fair, political system should not exclude any member from a right on political participation or discriminate against anyone based on gender, race, education or the like. I have outlined that the current electoral system tends to discriminate some people based on their social, educational and financial backgrounds and that therefore some people hardly have access to actual influence, since their right to vote has almost no impact. To support this claim that people have reason to strive for a political system that provides them with a relevant impact, I will elaborate on a relevant understanding of political influence in the next section.

\section{Political Equality as Vertical Equality of Influence}

To illustrate further the demand for equalizing the distribution of political power, I want to build on a distinction proposed by Ronald Dworkin. Dworkin differentiates, on the one hand, between horizontal and vertical political equality, on the other hand he understands political equality as either equality of influence or of impact. This distinction might help to illustrate what kind of equality lottocratic systems can provide and especially provide better than electoral democratic systems.

With horizontal equality he refers to an equal political power amongst individual citizens or groups of individuals. With vertical equality he refers to an equal political power between private citizens and individual officials (cf. DwORKIn I987, 121). Such vertical equality seems to be both unrealistic, because it is impossible to provide every citizen with the same power as a congresswoman or the president, and not necessarily desirable regarding the complexities of political systems and the capacities required to take good political decisions. To demand that every single citizen has the same impact on political decisions would undermine the concept of representation, which aims to transmit the power of the citizens to some chosen, competent representatives. 
Nevertheless, to ignore the vertical inequality of power, between the citizens on the one hand and some selected politicians or otherwise influential elites on the other hand, contradicts the claim for political equality. Electoral democracies might be said to realize an equal horizontal power amongst all people, but this does not yet satisfy the requirement of an equally distributed political power if one understands political power as "the capacity to realize a possible desire, or to get what one wants, despite resistance" (BeITZ I989, 8). Having one equal vote does not provide one with the same power as an elected politician or a member of the influential elite. To demand only equality of horizontal power seems to be no sufficient criterion for a system to satisfy the claim for political equality in a relevant way: even in a totalitarian system all people (except the dictator) have the same horizontal power - none - and also in a one-party-system every person has the same say - one vote - but no actual choice and influence on political outcomes. Thus, a merely equal distribution of votes amongst all citizens is not a sufficient requirement for a fair distribution of power. What is necessary instead is to provide them with an equal and relevant impact on politics. Even if a system provides everyone with an equal and influential vote, one cannot claim that such a system actually provides everyone with the same power: only a selected amount of people - the elected politicians and some other influential people - is provided with effective political power, while the actual influence of the will of every single voter is questionable.

Dworkin, therefore, introduces another relevant dimension for measuring the quality of political power: the distinction between equality of impact and equality of influence. These categories can be described as follows:

someone's impact in politics is the difference he can make, just on his own, by voting for or choosing one decision rather than another. Someone's influence, on the other hand, is the difference he can make not just on his own but also by leading or introducing others to believe or vote or choose as he does (DwORKIN I987, 122)

The influence one has depends on non-constitutional facts such as "the power of charisma or reputation or association or skill or threat or bribe or other advantages that give any one person influence over the political acts of anyone else" (Ibid.). Although having a same vote provides one with the same impact, such non-constitutional facts make the actual influence of every voter unequal. Given the above-mentioned non-constitutional conditions like charisma or potential of bribery, the opinions of some people are more influential than the opinions of others. When these more influential people 
change their opinion, they have the power of changing the voting-behavior of others. Although they still possess only one, equally weighed vote, they can convince others to change their votes accordingly. When a non-influential, average voter changes her opinion, this does only change one single vote. While the political structure, the voting rights and the constitutional facts of a community are relevant for the impact of every single voter, the non-constitutional power of charisma, reputation, network and others determine the influence of a single voter.

This distinction helps to solve the dilemma stated above: vertical equality of impact is impossible and horizontal equality of impact is not necessarily significant. But vertical equality of influence would indeed improve the responsiveness of a political system and horizontal equality of influence could solve the problem of minorities not having any chance of imposing their interests. As mentioned above, the simple condition of a same vote does not say a lot about the quality of a democracy. Equal impact, therefore, is not necessarily a relevant criterion for a fair distribution of political power. Equal influence is a more helpful concept instead. It includes such relevant features as a right on freedom of speech and association, which are necessary virtues for a system to be a democracy. Someone's impact in politics is not smaller than someone else's impact if one of them is denied the freedom of speech while guaranteed a right to vote, but his political influence is reduced unfairly if he is denied such a right to speak.

The concept of horizontal equality of influence can also help to explain another serious complaint about current democratic systems, namely the fact that some financially or medially powerful people have disproportionally more political power than others although they are only citizens and no elected politicians (cf. i.a. Guerrero 20i4; Hartmann 20i8). Such people have the same impact as any other voter but they have more influence due to their networks and their possibilities of reaching and influencing other people. According to Richard Arneson it is especially a difference in horizontal influence that we consider unfair. A society is considered more democratic the closer it comes to achieving equality of influence, that is, the more independent access to political offices and influence on political decisions become from social status, social networks, sex, race, education level and the like (cf. Arneson 2009, 199).

The distinction between equal impact and equal influence helps to justify the egalitarian value of lottocracy. I will argue that providing everyone with an equal chance to gain considerable influence by being drawn by lot outweighs the deprivation of a guaranteed but minimal equal impact through a right to vote. Given the aforementioned intrinsic value of equality 
and procedural fairness, I take it as granted that political power should be distributed equally ${ }^{11}$.

I have elaborated earlier on the mathematically small weight of every single vote (cf. i.a. ARneson 2009, 201; KolOdNy 20 I4, 218). I take this as a starting point in order to support the claim that an effective chance on influence is in a relevant way more egalitarian and therefore more important than a guaranteed right to vote. Mathematically speaking, the chance of becoming drawn by lot as a politician would still be pretty small. Nevertheless, in a lottocratic system the access to political influence would become more egalitarian because systemic and contingent hurdles to democratic access would be reduced. Electoral democracies provide every citizen with the same impact, but proponents of lottery-based proposals criticize the very fact that political influence is distributed highly unequally in electoral democracies ${ }^{12}$ : mainly contingent factors such as charisma, financial power and social networks influence who becomes politically influential. The impact of such contingent factors could be cut out, or at least significantly reduced, in lottocracies and effectively everyone would have the chance to gain political influence, also people from lower social strata, with lower educational levels or smaller social networks.

Electoral systems, at least as they are designed and practiced at the moment, do effectively not provide everyone with an equal chance on political influence. As Aristotle puts it, elections are oligarchic and only the lot is democratic, because elections do already preselect certain candidates to be eligible, while lottery-selection does provide everyone with the possibility to become selected (cf. AristotLe, 350bc (i 885 ) book IV, part ix, 1294b). Electoral systems, as they currently are, are not egalitarian for two reasons: on the one hand, the passive right to be eligible is effectively not realized for everyone; on the other hand, the politicians eligible do oftentimes not provide one with the possibility of being demographically represented, that is represented in terms of age, educational background, values or the like. The process of elections is in a certain way selective, thus that the elected politicians and people politically committed are over all not demographically representative to the society and

${ }^{11}$ Besides of the intrinsic motivation of this demand, proponents of equal access to political power also stress the instrumental value of including as diverse opinions and skills as possible in political decision making. Critics question whether the benefits of cognitive diversity and descriptive representation do really outweigh the cost of losing the presumably positive traits of charisma, personal motivation and expertise which elected politicians might have. Again, I have to leave this discussion of instrumental arguments to another occasion and will focus on the equality of access to political influence here.

${ }^{12}$ Again, this is not supposed to imply that lottocracy is the only way to reach such an improvement. Electoral systems might be improved in a way to provide people with an equal chance on influence, but I am concerned with pointing at the egalitarian potential of lottocracy here and not with suggesting improvements of electoral democracy. 
therefore their opinions are likely not to cover all topics or options relevant to the different groups of the society. In a lottocracy, people from all social strata could be selected and would be more representative for the society as a whole than current politicians ${ }^{13}$.

The concept of demographic representation is important for my claim that lottocracy would distribute political influence more equally than electoral democracy. Representation is considered an institutional device to make democratic decision-making possible when numbers are too large (cf. LANDEMORE $2013,105)$. Representation can be understood as "acting for someone" or "descriptively standing for someone" (cf. PITKIN 1972). Arguments for a form of political representation, where some people are selected in order to act for others mainly build on some special abilities these selected have, such as rhetorical competence or intellectual expertise on a topic. But this causes the problem that elections "tend to bring to power socially and economically homogenous people. [... These] people are likely to share some personality traits (a type A personality, say) or other characteristics that may reduce the overall cognitive diversity of the assembly" (LANDEMORE 2013, 108). This cognitive diversity is what a descriptive understanding of representation aims at. Research has shown that the quality of decisions highly depends on the amount of different perspectives included in a decision, rather than on the cognitive ability of every single participant of the deliberation. The Diversity Trumps Ability Theorem holds that "a randomly selected collection of problem solvers outperforms a collection of the best individual problem solvers" (PAGE 2007, 163) ${ }^{14}$. Empirical experiments have shown that "groups of average citizens perform decently well when placed in the right deliberative conditions" (LANDEMORE 20I3, 109). If the aim is to reproduce the diversity of the society, elections are not the best way of ensuring this, since, at least in current electoral systems, they

${ }^{13}$ Considering the laws of probabilities, it is of course not guaranteed that a lottery-based parliament could represent all minorities of a society, it is not even guaranteed that social structures would be roughly mirrored at all. Nevertheless, what lottery-based selection could overcome at once are systemic hurdles, which currently hinder some people from becoming eligible or elected. Lottery-selection is of course not the only way to solve this problem and ideal electoral democracies would not impose such systemic hurdles. Still, probabilities are higher in lotteryselected groups than in election-based systems that members of currently under-represented groups get selected. A completely random selection cannot ensure the representation of minorities but makes it more likely than the current election system. Some proponents of lotterybased systems propose to implement quota in order to ensure the representation of minorities. I cannot elaborate on the advantages and disadvantages of such proposals here further but am aware of the need to address the problem of ensuring the representation of minorities, which I claim lottery-selection could provide, elsewhere. Thanks to an anonymous reviewer for pointing out the need to clarify this.

${ }^{14}$ For an interesting and illustrative description of this see Landemore (2013, 99-102). 
tend to bring to power people with similar personality traits and social backgrounds. When it comes to descriptive representation, random lotteries would produce "'an exact portrait, in miniature, of the people at large', ensuring a statistical similarity of thoughts and preferences of the rulers and the ruled" (Ibid., 108). In order to reach as much cognitive diversity as possible, without knowing beforehand which perspectives, concerns and convictions might be needed to come to the best solution, "it seems that the best solution is not to choose but to leave it up to chance and the law of large numbers" (Ibid., 115).

The claim for descriptive representation blurs the line between the procedural and the instrumental quality of democracy. Although I generally want to exclude content-related arguments in this paper, including the quality of deliberation has definitely both a procedural and an epistemic aspect. The argument for aiming for a descriptive representation rather than for a representation in the sense of acting for someone builds on the epistemic quality of the decision taken. But the consequence of demanding such a descriptive form or representation is a procedural one. In order to generate a descriptive representation of the society, the procedure of random selection is more feasible than elections.

If one understands representatives as actually "communicating" with the people they represent, and as merely expressing their opinions, then demographic representation might be rather irrelevant. But if one understands representation as representing the people's attitudes and cognitive abilities, then descriptive demographic representation becomes more important (cf. PIтKIN I972). The problem of political representation is that a political representative is "neither an agent nor a trustee nor deputy nor commissioner; he acts for a group of people without a single interest, most of whom seem incapable of forming an explicit will on political questions" (Ibid.). Therefore, the most relevant understanding of representation seems to be to mirror the opinions present in a society. Political representation should ensure that the opinions of all people are equally present in a governmental action, and this is likely to be realized better when the people are descriptively represented and not merely acted for by someone.

I can now consolidate the two lines of argument developed above. I have spelled out why the desirable form of political equality should be an equal influence rather than an equal impact. Besides, I argued that political representation should be rather descriptive than in the sense of acting for someone. Elections provide everyone with an equal impact but with only a limited access to political influence. The impact of every single vote is diminishingly small and insignificant. The chance on actual political influence is distributed very unevenly in electoral democracies and would be distributed fairly in lottocracies. Given the fact that, practically speaking, not everyone can have a significant 
influence, I argued that descriptive representation is more promising in order to ensure that everyone's interests are addressed than an acting-for representation. In order to mirror the attitudes and the diversity of the society, random selection is a promising procedure to distribute the chance on influence procedurally fair and to reproduce the cognitive diversity of the society. Even if one is not selected, one's own interests and attitudes would probably be represented better in a demographically descriptive parliament than in a parliament where one has merely the chance to elect people which tend to be mainly from one social strata.

\section{Conclusion}

The aim of this paper was to examine the egalitarian quality of so called lottocratic political systems. At first glance, depriving people of their right to vote might seem to violate the basic requirements of political equality and participation. Still, I claimed that lottocratic systems do nevertheless satisfy a relevant understanding of equality.

First, I pointed out that electoral democracies are highly un-egalitarian themselves when it comes to equality of influence or the representation of demographic facts. I argued that an equal chance on being selected can be considered a sufficient realization of procedural accounts of democracy and therefore satisfies the requirement of political fairness. Second, I put forward that given the minimal mathematical impact of every single vote and given the merits of a descriptive account of representation, vertical equality of influence should be considered a more relevant form of political equality than a guaranteed equal but small impact.

Having shown that lottocratic systems can be considered egalitarian in a relevant sense, the legitimacy of lottocratic systems seems to depend mostly on their instrumental value and the epistemic quality of their decisions. This issue is, however, left for future research.

\section{Acknowledgements}

I would like to thank the participants of the XX Taller d'Investigació en Filosofia 2019 in Valencia and Thomas Krödel, Stephan Schmid and the participants of their research colloquium at the University of Hamburg for very helpful comments on earlier drafts of this paper. Moreover, I am thankful to Moritz Schulz for providing me with the financial funding to realize this paper. 


\section{BiBLIOGRAPHY}

Aristotle (350bc (i 885$)$ ), Politics (B. Jowett, trans.), Oxford: The Clarendon Press.

Arneson, R. J. 2009, "The Supposed Right to a Democratic Say", T. Christiano \& J. Christman (ed.), Contemporary Debates in Political Philosophy, West Sussex: Wiley-Blackwell, 197-212).

Beitz, C. R. I989, Political Equality - An Essay in Democratic Theory, Princeton, NJ: Princeton University Press.

Berbner, B. et al. 20i7, 2.2, „Zur Wahl steht: Die Demokratie“, Die Zeit. Retrieved from https://www.zeit.de/2017/04/rechtspopulismus-demokratiewahlen-buer gerversammlungen-politisches-system-griechenland. Accessed: 20.02.2019

Christiano, T. i996a, "An Argument for Democratic Equality", T. Christiano (ed.), Philosophy and Democracy. (2003), Oxford, New York: Oxford University Press, 39-68.

Christiano, T. г996в, "Democracy As Equality”, D. Estlund (ed.), Democracy, Oxford: Blackwell Publishers, 31-50.

Christiano, T. 20 18, "Democracy", The Standford Encyclopedia of Philosophy, Fall 2018 Edition, E. N. Zalta (ed.). Retrieved from https://plato.stanford.edu/ entries/democracy/\#Bib.

Cohen, J. I996, "Procedure and Substance in Deliberative Democracy", T. Christiano (ed.), Philosophy and Democracy. (2003), Oxford, New York: Oxford University Press, 17-38.

Cwiertnia, L. 20i 8, 9.8, „Sie leben in einer völlig anderen Welt“, Die Zeit. Retrieved from https://www.zeit.de/2018/33/michael-hartmann-eliten-soziologie-soziale-gerechtigkeit. Accessed 20.02.2019.

Dworkin, R. I987, "What is equality? Part 4: Political equality", T. Christiano (ed.), Philosophy and Democracy. (2003), Oxford, New York: Oxford University Press, 116-37.

Estlund, D. I997, "Beyond Fairness and Deliberation”, J. Bohman \& W. RehG (ed.), Deliberative Democracy, Cambridge, Massachuesetts: MIT, 173-204.

Estlund, D. 2008, Democratic Authority - A philosophical framework, Princeton, Oxford: Princeton University Press.

Fishkin, J. S. 2009, When the People Speak, Oxford: Oxford University Press.

FishKin, J. S. 20 I 8, Democracy when the people are thinking: revitalizing our politics through public deliberation, Oxford: Oxford University Press.

Frankfurt, H. I987, "Equality as a Moral Ideal”, Ethics, vol. 98 (1 (Oct., 1987)): $21-43$. 
Frankfurt, H. 2000, “The Moral Irrelevance of Equality”, Public Affairs Quarterly, vol. 12 (2): 87-103.

Fuchs, D. 2009, „Demokratie“, D. Fuchs \& E. Roller (ed.), Lexikon Politik, Stuttgart: Reclam.

Guerrero, A. A. 2014, "Against Elections: The Lottocratic Alternative”, Philosophy \& Public Affairs, vol. 42 (2): 135-78.

Hartmann, M. 2018, Die Abgehobenen: Wie die Eliten die Demokratie gefährden, Frankfurt: Campus Verlag.

Helm, M. 2017, 14.9, „Wenn Wahlkampf eine Frage des Geldes ist“, Süddeutsche Zeitung. Retrieved from https://www.sueddeutsche.de/politik/bundestagswahl-wenn-der-wahlkampf-eine-frage-des-geldes-ist-1.3624810. Accessed 20. 02.2019.

Huemer, M. 2013, The Problem of Political Authority - An Examination of the Right to Coerce and the Duty to Obey, Hampshire: Palgrave Macmillan.

Kolodny, N. 20 I4, "Rule Over None I: What Justifies Democracy?”, Philosophy \& Public Affairs, vol. 42 (3): 195-229.

Landemore, H. 2013, Democratic Reason, Princeton, NJ: Princeton University Press.

Lincoln, A. I 863, "The Gettysburg Address", W. E. Gienapp (ed.), This Fiery Trial: The Speeches and Writings of Abraham Lincoln (2002), Oxford: Oxford University Press.

López-Guerra, C. 20 i I, "The Enfranchisement Lottery", Politics, Philosophy and Economics, vol. 10 (2): 211-33.

Page, S. E. 2007, The Difference: How the Power of Diversity Creates Better Groups, Firms, Schools, and Societies, Princeton, New Jersey: Princeton University Press.

Pitkin, H. F. I972, The Concept of Representation, Berkley and Los Angeles: University of California Press.

Rawls, J. I97I, A Theory of Justice, Cambridge: Harvard University Press.

Robertson, D. 2004, “Democracy”, D. Robertson (ed.), The Routledge Dictionary of Politics (3rd ed.), London, New York: Routledge.

Saunders, B. 20 io, "Democracy, Political Equality, and Majority Rule", Ethics, vol. 121 (1, October 2010): 148-77.

Schmidt-Mattern, B. 2015, Deutschlands Akademiker-Parlament. Deutschlandfunk. (ed.). Köln: Deutschlandradio. Retrieved from http://www. deutschlandfunk.de/demokratie-deutschlands-akademiker-parlament.862. de.html?dram:article_id=334191. Accessed 9.7.2017.

Statistisches Bundesamt, destatis. 2017, Bildungsstand - Bevölkerung nach Bildungsabschluss in Deutschland. Wiesbaden: Statistisches Bundesamt. Retrieved from https://www.destatis.de/DE/ZahlenFakten/GesellschaftStaat/BildungForschungKultur/Bildungsstand/Tabellen/Bildungsabschluss.html. Accessed 21.3.2018. 
United Nations, The Universal Declaration of Human Rights (1948).

Van Reybrouck, D. 2016, Gegen Wablen - Warum Abstimmen nicht demokratisch ist, Göttingen: Wallstein Verlag.

Van Reybrouck, D. 20 i 8, Against Elections - The Case for Democracy, New York: Seven Stories Press. 